\title{
Communicative intentions and pragmatic objectives realizing in the interview by its collective authors
}

\author{
O. O. Salamatina*, A. V. Markowska, O. V. Artyukhova, Zh. V. Ihnatenko \\ Mykolayiv National Agrarian University, Foreign Languages Department \\ *Corresponding author. E-mail: olga.salamatina555@ukr.net
}

Paper received 27.01.19; Accepted for publication 02.02.19.

\section{https://doi.org/10.31174/SEND-Ph2019-190VII56-11}

\begin{abstract}
The article reveals the communicators' interaction specificity in modern publicistic interview. By analysis of the interviews in the modern English-language press the interviewer's and respondent's strategies are determined and compared: the speech strategies of information getting and granting, the point of view expression strategies which depend on desire or unwillingness to give the socially important information. Interviewer's and respondent's speech tactics, aimed at realizing their communicative intentions and pragmatic objectives have been characterized.
\end{abstract}

Keywords: interviewer, respondent, communicative intention, speech tactics, pragmatic objective.

Introduction. Modern science is characterized by the tendency to study publicistic texts of different genres as one of the main sources of society's information reception: newspaper sports discourse (A.V. Kikalo [5]), diagnostic news (D. Maynard [15]) and others. However an interview is one of the brightest speech genres in general and Publicism in particular, that help to distribute social information on the mass and distant located audience. But this kind of texts can not only be studied as a genre of Journalism as it has the accurately expressed communicative organization and pragmatic potential. So it can also be a view to exploring by Linguistics.

Brief publications overview on the topic. Expressive, emotional and estimating descriptions of publicistic interview (K.V. Oleksandrenko [6]) have acted as object of analysis lately; functional and stylistic features of interview in press (M. P. Podolyan [7], V. I. Provotorov [8]) in particular in correlation with other types of discourse (T. V. Bukhinska [4]) and cognitive signs of publicistic interview (L. R. Bezugla [2]) have also been studied.

Objective. Nowadays in spite of different linguistic researches of separate features in publicistic interview the problem of analysis of linguistic specificity of interview in press as a speech genre, taking into account its communicative and pragmatic signs, remains unresolved. So in the article we have to determine linguistic specificity of interview in press as a speech genre; to characterize and compare the interviewer's and respondent's speech tactics, aimed at realizing their communicative intentions and pragmatic objectives.

Materials and methods. The texts of interview from the modern English-language press chosen at random served as material base for the research. The main methods used in the work are: comparative method, method of linguistic observation, context-situational and pragmaticsemantic methods. They helped to segregate speech strategies and tactics of collective authors in the interview.

Results and their discussions. As interviewer and respondent pursue obvious and hidden aims in texts of interview, they are forced to use the certain pragmatic strategies, each of which consists of differet speech tactics, that help to use these strategies during the interview. Pragmatic strategy is determined as planning of construction of speech interaction process depending on the certain conditions of dialogue, interviewer's and respondent's personalities. The tactics of speech interaction is expressed by the certain speech actions which have for a purpose realization of influence on the other participant of communication on the certain stage of interaction. The orientation of various tactical receptions on achievement of certain pragmatic objective lines up in speech strategy $[10$, p. 163; 11, p. 96].

In the process of analyzing willfully selected texts in the interviews of the modern English-language press, a speech strategy of getting information by the interviewer was found the aim of which is to get the necessary data from the interlocutor. The "direct question" tactics has the task to help the interviewer to get some information about the problem which is posed. This tactics is most commonly used in the texts which are studied in this research. For example:

- Do you believe, that the visitors of our National Park will display the keen interest?

- Yes, I do (The Times Magazine). In addition, the interviewer sometimes uses tactics "hidden question", the task of which is to obtain information without disclosing interviewer's direct intentions [12, p. 94]. "Indirect question" is used when the direct request is not tactful toward interlocutor; the interviewer tries to make the respondent the initiator of disclosing the "awkward" topic. The tactics "joint forecasting" is to interpret mutually and to predict by interviewer and respondent the development of events in an interview [12, p. 95]. The tactical course of the interviewer is a proposal for the respondent to develop the proposed topic. The indicated "direct question" and "hidden question" tactics are sometimes combined with the tactics of "reincarnation" and "transference". The tactics "reincarnation" is in the fact that the interviewer in the modern English-language journalistic interview artificially establishes a gap in knowledge with the respondent; he asks what is already known in order to obtain more information from the respondent. The interviewer takes the ignorance of the main issue of the interview. Trying to disclose the views of the respondent as fully as possible, he should not argue or criticize his views $[14, \mathrm{p} .1]$; otherwise it will lead to an entirely opposite result. The respondent will get isolated and will not be able to continue the interview, or he will not respond frankly. If the speech act of the interviewer contains negative information about the interlocutor, which he must confirm or refute, the journalist applies to the tactics of "transference" [1]. In 
today's English-speaking publicistic interview due to this tactics, the interviewer tries to avoid negative attitude to him on behalf of the respondent, leaving a positive selfpresentation. He usually refers to the source of negative information and thus maintains his neutral status.

Investigating the interview in the modern Englishlanguage press, we came to the conclusion that in texts of this type the interviewer uses tactics that contribute to express his point of view on the problem which he asks to comment in order to influence the respondent $[7, \mathrm{p} .15$; 16 , p. 239-240; 18, p. 391]. The pragmatic strategy of the point of view expression is represented by tactical courses: "convergence", "circumspection", "thought expression", "generalization", "concretization". The tactics "convergence" is used in the situation where the interviewer allegedly "comes closer" with the respondent, disguising himself to a person who has the same status as the respondent. Thus, the interview starts to resemble the conversation and allows the interviewer to inquire from the respondent as much information as possible.

The tactics "circumspection" was discovered by J. Bergmann [13] in a specialized institutional discourse: report of unpleasant medical news and diagnosis. In these cases, it is the interviewer, and not the respondent who knows much, and tactics of "circumspection" hides his awareness of the unpleasant facts associated with the respondent. The tactics "thought expression" is in the fact that the interviewer invites the respondent to express his point of view, and then issues his own opinion on the topic $[15$, p. $165 ; 17$, p. 592], receiving control over the way of the interview. Tactics "generalization" and "concretization" are used if the interviewer tries to direct the respondent's answer in his wishful direction [17, p. 592].

The respondent's speech strategies in the modern interview have been also determined: the speech strategy of information granting and the point of view expression. In this work we need to consider the features of the respondent's strategies on the example of interview in the modern English-language press, and also to define general descriptions of speech tactics, used by respondent in order to achieve his pragmatic objective.

The peaceful speech strategy of information granting is connected with respondent's desire to give useful information to the interviewer. For realization of this strategy interviewer uses several tactics. The tactics "direct answer" can be connected with a joke, it helps respondent to facilitate the process of communication. In some cases respondent can't or does not want to reply "yes" or no" to the interviewer's question. That's why he uses the tactics "unwrapped answer", giving detailed information. Using the "unwrapped answer", respondent enables interviewer to estimate the propositional content of the question from point of reality or authenticity. Sometimes respondent can use the tactics "management". Such tactics is an exchange of roles between interviewer and respondent, respondent obtains possibility to change the role of listener on the role of speaker. It can be expressed by the rhetorical question for introduction of the new information which is reported by the speaker. Respondent asks for permission to explain the opinion. Question "May I explain?" appeals to the personal interest of interlocutor with the purpose of paying his attention to the next report. Respondent wishes to prove the answer, to give as much information as pos- sible. The analysis of interview in the modern Englishlanguage press displayed that the tactics "management" is more or less widespread in the texts of interview, but within the limits of one text respondent usually elects this tactics only in one minimum dialogue unit which is explained by the social roles of interaction participants and institutional nature of the interview of press.

As it was mentioned above, unlike interviewer respondent does not always use peaceful speech strategies. Let's consider the conflict speech strategy of information granting. It is explained by unwillingness of respondent to give information or discuss a certain problem. In texts of interview it is presented by several tactics. One of them is the tactics "instructions on irrelevance of a question". Evading from the direct answer of the question respondent marks that the question is not appropriate in the present situation ("at the wrong door"). Negative sentence testifies to it. Sometimes respondent can use the tactics "short answer" answering just "yes" or "no". Such tactics demonstrates the unwillingness of respondent to continue the conversation on the offered theme. Respondent's speech motion which is a simple sentence testifies to it. An interviewer can not be satisfied with such answer, as he expects the detailed information. As the analysis of the researched interviews of the modern English-language press testifies, interviewer may use the tactics "counter question", for example:

- Are you happy now?

- And you? (Financial Times). Such tactics allows respondent to ignore the interviewer's question. It specifies on the respondent's unwillingness to answer the question of intimate character; he tries to remove the moment of answering it. The other conflict tactics of the information granting strategy is the tactics "ignoring", when respondent does not know the answer of the interviewer's question and that is why repeats phrases which have already been said.

The speech strategy of the point of view expression is used by respondent as a reaction upon hidden request of information. Reacting on speech motion of interviewer, respondent expresses his point of view-attitude to the certain situation or point of view-explanation of reasons, phenomena and facts, expressed by interviewer. The peaceful strategy of the point of view expression is represented by several speech tactics. The tactics "direct consent" is represented by the complete coincidence of the partners' aims of the dialogue, interviewer's and respondent's informative volumes of remarks. In this case the interviewer's remark can be examined as the hidden inquiry of confirmation of the information correctness. The respondent's remark expresses confirmation and shows the correctness of interviewer's information. The tactics "explanation" foresees respondent's explanation of the interviewer's initial remark content. Respondent expresses the explanation of the phenomenon, which interviewer specifies in. Such explanation can concretize the content of the interviewer's initial remark or summarize it. Let's consider the example:

- When you were called a moral historian, I think what was also meant was that there is a sense of morality running through your work. 
- Good writers have to be moralists. You must have values. Without values you can't write. I can't think of a good writer who has not been a moralist (Newsweek).

In this minimum dialogue respondent uses the tactics "explanation". It is set between subject nominations replacing the personal pronoun "you" with a noun with the summarizing value "good writers".

The conflict speech strategy of the point of view expression is also represented by several tactics. During communication interviewer's and respondent's positions appear to be opposite quite often. Under the tactics "opposition" we understand a type of dialogical cooperation where the separate elements of answer are matched against the separate elements of initial remark on the basis of equation of most elements which are included in both remarks [9]. In the field of contrasting the tactics "full discrepancy" and "partial discrepancy" have been realized. The tactics "disagreement explanation" of respondent explains, why exactly respondent disagrees with the interviewer's claim, for example:

- You have spoken too much about death.

- You have misunderstood me. I have only mentioned that I am afraid of death. I'm not going to die, I'm happy to live (The Times).

The conflict speech strategy of the point of view expression can be realized by the tactics "displaced answer", which is related to the forced or relaxed inadequate interpretation of interviewer's communicative intention and propositional content of the initial remark. The result of interpretation inadequacy is violation of logical motion of the dialogue. The tactics "instructions on irrelevance of the statement" specifies on irrelevance and absurdity of the interviewer's remark content. The respondent's purpose is to stop talking on a certain theme or changing its character. Respondent sometimes uses the tactics "silence". Under "silence" we understand the communicative meaningful silence which executes a certain sign function in verbal communication. It should be noted that in the researched texts of interview in the modern English language press "silence" is rarely used, it isn't typical for this kind of discourse.
Findings. Analisys of the texts of interview from the modern English-language press chosen at random displayed, that the strategies, used in interview by its collective authors may be either peaceful [3, p. 115], or conflict [12, p. 92] in dependence on respondent's and interviewer's interaction method: by cooperation or through a conflict. Thus, respondent uses peaceful or conflict communicative strategies in texts-interviews. They depend on his desire or unwillingness to give the public information to interviewer and on positive or negative attitude to the interviewer's remark. Depending on his communicative objective respondent chooses the speech strategy of information granting or the point of view expression. The speech strategy of information granting is represented by such peaceful tactics: "direct answer", "unwrapped answer", "management" and by the conflict tactics: "instructions on irrelevance of a question", "short answer", "counter question" and "ignoring". The point of view expression is presented by the peaceful speech tactics: "direct consent", "explanation", and also by the conflict tactics: "opposition", "full discrepancy", "partial discrepancy", "disagreement explanation", "displaced answer", "instructions on irrelevance of the statement" and "silence". Interviewer as compared with respondent is aimed at getting as much information from his interlocutor as possible, so it is disadvantageous for interviewer to set respondent against. That's why his speech strategies of getting information and the point of view expression are peaceful. The speech strategy of getting information is presented by the peaceful speech tactics: "direct question", "hidden question", "indirect question", "joint forecasting", "reincarnation", "transference". The pragmatic strategy of the point of view expression of the interviewer is represented by tactics: "convergence", "circumspection", "thought expression", "generalization" and "concretization". All the tactics, which are used by interviewer and respondent in the modern English-language press, are directed on realization of their communicative intentions and pragmatic objectives. The results of this work can be used for subsequent linguistic researches of the communicative and pragmatic features of texts of different types.

\section{ЛИТЕРАТУРА}

1. Апалат Г. П. Структура, семантика і прагматика текстів інтерв'ю (на матеріалі сучасної англомовної преси) : дис. ... канд. філол. наук : 10.02.04 / Апалат Ганна Павлівна. K., 2002. $-203 \mathrm{c}$.

2. Безугла Л. Р. Когнітивно-прагматичні характеристики імпліцитних смислів у німецькомовному дискурсі : дис. ... доктора філол. наук : 10.02.04 / Безугла Лілія Ростиславівна. - Х., 2008. -428 с.

3. Бендецкая М. Е. Стратегии и тактики речевого убеждения / М. Е. Бендецкая // Стратегии коммуникативного поведения : междунар. науч. конф., 3-4 мая 2001 г. : тезисы докл. - Минск, 2001. - С. 115-118.

4. Бухінська Т. В. Розмір та частота вживання різних типів речень у німецькій мові (на матеріалі художньої прози та публіцистики) : дис. ... канд. філол. наук : 10.02.04 / Бухінська Тетяна Вікторівна. - Ч., 2007. - 250 с.

5. Кікало А. В. Комунікативно-прагматичні особливості спортивного тексту французької преси : дис. ... канд. філол. наук : 10.02.05 / Кікало Анжеліка Василівна. Ужгород, 1995. - $154 \mathrm{c}$.

6. Олександренко К. В. Екстралінгвістичні фактори створення експресивності у газетній комунікації / К. В. Олек-

сандренко // Актуальні проблеми філології та перекладознавства : зб. наук. пр. - Хмельницький : ХНУ, 2007. Вип. 3. - С. 94-96.

7. Подолян М. П. Публіцистика як система жанрів / Подолян М. П. - К. : Наукова думка, 1998. - 220 с.

8. Провоторов В. И. Очерки по жанровой стилистике текста (на материале немецкого языка) / Проворотов В. И. Курск : изд-во РОСИ, 2001. - 288 с.

9. Саламатіна О. О. Мовленнєвий жанр «інтерв'ю» в сучасній німецькомовній та україномовній пресі: функціональні та прагматичні ознаки : дис. ... канд. філол. наук : 10.02.015 / Саламатіна Ольга Олександрівна. - Одеса, 2011. $-228 \mathrm{c}$.

10. Семенцова I. М. Комунікативна стратегія як елемент теорії комунікації / І. М. Семенцова // Мовні концептуальні картини світу : зб. наук. пр. - К. : Прайм-М, 2002.№ 6. - С. 161-166.

11. Сысоева Т. А. Реализация стратегий автора в текстах массовой коммуникации / Т. А. Сысоева // Стратегии коммуникативного поведения : междунар. науч. конф., 34 мая 2001 г. : тезисы докл. - Минск, 2001. - С. 95-99. 
12. Чайка Л. В. Питальні висловлювання у комунікативному аспекті (на матеріалі англійської мови) : дис. ... канд. філол. наук : 10.02.04 / Чайка Лариса Василівна. - К., 1998. - $165 \mathrm{c}$.

13. Bergmann J. R. Veiled morality : Notes on discretion in psychiatry / J. R. Bergmann // Talk at Work : Interaction in Institutional Settings. - London and New York : Longman, 1992. - P. 137-162.

14. Heritage J. Grammar and institution : Questions and questioning in the broadcast news interview / J. Heritage, A. L. Roth // Research on Language and Social Interaction. - 2005. - Vol. 28, № 1. - P. 1-60.

15. Maynard D. W. The perspective-display series and the delivery and receipt of diagnostic news / D. W. Maynard // Talk and Social Structure / [Ed. by D. Boden and D. H. Zimmerman]. - Cambridge : Polity Press, 1991. - P. 164-192.

16. Mishler E. G. The interactional production of narrative accounts / E. G. Mishler // The Construction of Professional Discourse / [Ed. by B.-L. Gunnarsson, P. Linell and B. Nordberg]. - London and New York : Longman, 1997. - P. 223 244.

17. Rapley M. "What do you think about...?" Generating views in an interview / M. Rapley, Ch. Antaki // Text. - 1998. Vol. 18, № 4. - P. 587-608.

18. Trinch Sh. L. Narrating in protective order interviews : A source of interactional trouble / Sh. L. Trinch, S. BerkSeligson // Language in Society. - 2002. - Vol. 31, № 3. - P. 383-418.

\section{REFERENCES}

1. Apalat H. P. Structure, semantics and pragmatics of the textsinterview (on the material of the modern English press) : thesis for a candidate degree in philology, speciality : 10.02.04 / Apalat Hanna Pavlivna. - K., 2002. - 203 p.

2. Bezuhla L. R. Cognitive-pragmatic characteristics of implicit meanings in the German-speaking discourse : thesis for a doctor degree in philology, speciality : 10.02.04 / Bezuhla Liliia Rostyslavivna. - Kh., 2008. - 428 p.

3. Bendetskaya M. E. Strategies and tactics of speech persuasion / M. E. Bendetskaya // Strategies of communicative behavior : The Intern. Scientific Conf., May 3-4, 2001 : Abstracts of the reports. - Minsk, 2001. - P. 115-118.

4. Bukhinska T. V. The size and frequency of the use of different sentences types in German (on the basis of artistic prose and journalism) : thesis for a candidate degree in philology, speciality : 10.02.04 / Bukhinska Tetiana Viktorivna. - Ch., 2007. $-250 \mathrm{p}$.

5. Kikalo A. V. Communicative-pragmatic features of the sports text in the French press : thesis for a candidate degree in philology, speciality : 10.02.05 / Kikalo Anzhelika Vasylivna. Uzhhorod, 1995. - $154 \mathrm{p}$.

6. Oleksandrenko K. V. Extralinguistic factors of expressiveness in the newspaper communication / K. V. Oleksandrenko // Actual problems of philology and perseverance : Collection of Scientific Works. - Khmelnytskyi : KhNU, 2007. - Edition. 3. - P. 94-96.

7. Podolian M. P. Publicism as a system of genres / Podolian M. P. - K. : Naukova dumka, 1998. - 220 p.

8. Provotorov V. I. Essays on the genre style in the text (on the material of the German language) / Provorotov V. I. - Kursk : izd-vo ROSI, 2001. - 288 p.

9. Salamatina O. O. Speech genre "interview" in the modern German-language and Ukrainian-language press: functional and pragmatic features : thesis for a candidate degree in philology, speciality: 10.02.015 / Salamatina Olga Oleksandrivna. - Odesa, 2011. -228 p.

10. Sementsova I. M. Communicative strategy as an element of communication theory / I. M. Sementsova // Language conceptual pictures of the world : Collection of Scientific Works. - K. : Praim-M, 2002. - № 6. - P. 161-166.
11. Syisoeva T. A. Implementation of the author's strategies in the texts of mass communication / T. A. Syisoeva // Strategies of communicative behavior : The Intern. Scientific Conf., May 3-4, 2001: Theses of the Report. - Minsk, 2001. P. 95-99.

12. Chaika L. V. Quotes in the communicative aspect (on the material of the English language) : thesis for a candidate degree in philology, speciality : 10.02.04 / Chaika Larysa Vasylivna. - K., 1998. - 165 p.

13. Bergmann J. R. Veiled morality : Notes on discretion in psychiatry / J. R. Bergmann // Talk at Work : Interaction in Institutional Settings. - London and New York : Longman, 1992. - P. 137-162

14. Heritage J. Grammar and institution : Questions and questioning in the broadcast news interview / J. Heritage, A. L. Roth // Research on Language and Social Interaction. - 2005. - Vol. 28, № 1. - P. 1-60.

15. Maynard D. W. The perspective-display series and the delivery and receipt of diagnostic news / D. W. Maynard // Talk and Social Structure / [Ed. by D. Boden and D. H. Zimmerman]. - Cambridge : Polity Press, 1991. - P. 164-192.

16. Mishler E. G. The interactional production of narrative accounts / E. G. Mishler // The Construction of Professional Discourse / [Ed. by B.-L. Gunnarsson, P. Linell and B. Nordberg]. - London and New York : Longman, 1997. - P. 223244.

17. Rapley M. "What do you think about...?" Generating views in an interview / M. Rapley, Ch. Antaki // Text. - 1998. Vol. 18, № 4. - P. 587-608.

18. Trinch Sh. L. Narrating in protective order interviews : A source of interactional trouble / Sh. L. Trinch, S. BerkSeligson // Language in Society. - 2002. - Vol. 31, № 3. - P. 383-418. 